\title{
Analysis on Trade Competitiveness and Trade Complementarity between Uzbekistan and the Member States of Eurasian Economic Union
}

Zhang Lingzhi

Tashkent State University of Economics, Tashkent, Uzbekistan

\begin{abstract}
Based on the 2010-2019 United Nations commodity trade data, this paper has calculated the regional revealed comparative advantage index, export similarity index, trade complementarity index and intra-industry trade index of trade between Uzbekistan and the member states of the Eurasian Economic Union. This paper analyses the competitiveness and complementarity of trade between Uzbekistan and the member states of the Eurasian Economic Union. Uzbekistan and the Eurasian Economic Union member countries have a high degree of similarity in the export of commodities. There is a certain degree of competitiveness in commodities exported to the same market. However, there are differences in the structure of commodity trade among member states. Uzbekistan's trade complementarity with the member states of the Eurasian Economic Union is distributed in food and live animals (SITC0), mineral fuels, lubricants and related materials (SITC3), manufactured goods classified chiefly by material (SITC6), commodities and transactions not classified elsewhere in the SITC (SITC9). Uzbekistan has strong trade complementarity with Armenia, Belarus and Kyrgyzstan, but weak trade complementarity with Russia and Kazakhstan.
\end{abstract}

Keywords: Eurasian Economic Union, Uzbekistan, Trade competitiveness, Trade complementarity, Export similarity index, Regional revealed comparative advantage index, Trade complementarity index, Grubel-Lloyd intra-Industry trade index.

\section{Introduction}

The member states of the Eurasian Economic Union are important trading partners of Uzbekistan. Since the establishment of the Customs Union of Russia, Belarus and Kazakhstan in 2010, the scale of trade between Uzbekistan and the member states of the Eurasian Economic Union has grown steadily. From 2010 to 2019, the trade volume Increased from 5.047 billion U.S. dollars to 8.423 billion U.S. dollars. In the past ten years, the trade volume between Uzbekistan and the member states of the Eurasian Economic Union has shown an upward trend. The trade situation between Uzbekistan and the member states of the Eurasian Economic Union from 2010 to 2019 is shown in Figure 1.

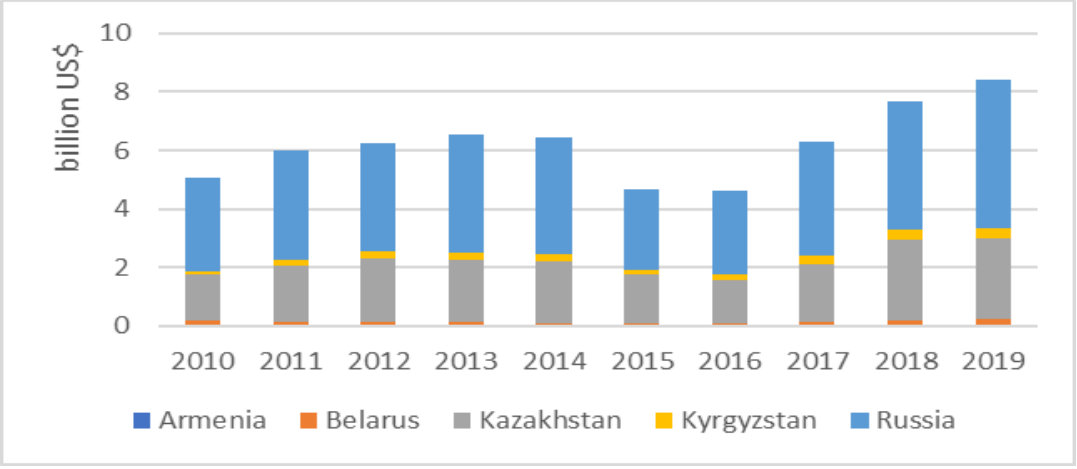

7 


\section{Zhang Lingzhi}

Analysis on Trade Competitiveness and Trade Complementarity between Uzbekistan and the Member

States of Eurasian Economic Union

Figure 1: Trade between Uzbekistan and the member states of the Eurasian Economic Union from 2010 to 2019

Source: UN Comtrade Database

It should be noted that the commodity trade data of this paper comes from the UN Comtrade Database, and SITC Rev. 4 is selected to collect the data. SITC Rev. 4 commodity codes:0-food and live animals.1-beverages and tobacco.2-crude materials, inedible, except fuels.3-mineral fuels, lubricants and related materials.4-animal and vegetable oils, fats and waxes.5-chemicals and related products, n.e.s.6-manufactured goods classified chiefly by material.7-machinery and transport equipment.8-miscellaneous manufactured articles.9-commodities and transactions not classified elsewhere in the SITC.

From the perspective of trade structure, from 2010 to 2019, the trade ratio between Uzbekistan and the member states of the Eurasian Economic Union was relatively stable: Russia was about $60 \%$, Kazakhstan was more than $30 \%$, and the remaining three countries were less than $10 \%$. Among Uzbekistan's exports to the member states of the Eurasian Economic Union, SITC0, SITC3 and SITC6 have a larger proportion. The export commodities are mainly agricultural and livestock products, resources and energy, and light industrial products, but the export value of SITC7 show a downward trend. The situation of Uzbekistan's exports to the member states of the Eurasian Economic Union from 2010 to 2019 is shown in Figure 2. The composition of Uzbekistan's imports of various commodities from the member states of the Eurasian Economic Union is relatively stable. Among them, the proportion of imports of SITC6 and SITC7 has increased significantly. The situation of Uzbekistan's imports from the member states of the Eurasian Economic Union from 2010 to 2019 is shown in Figure 3.

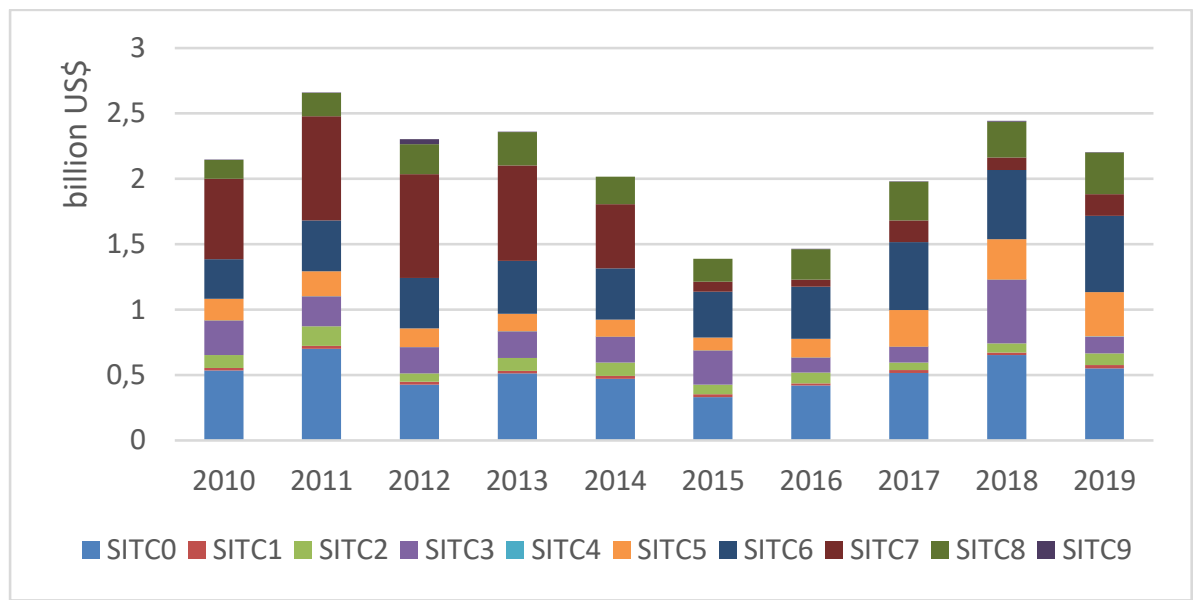

Figure 2: 2010-2019 Uzbekistan's export trade volume to the Eurasian Economic Union Source: UN Comtrade Database

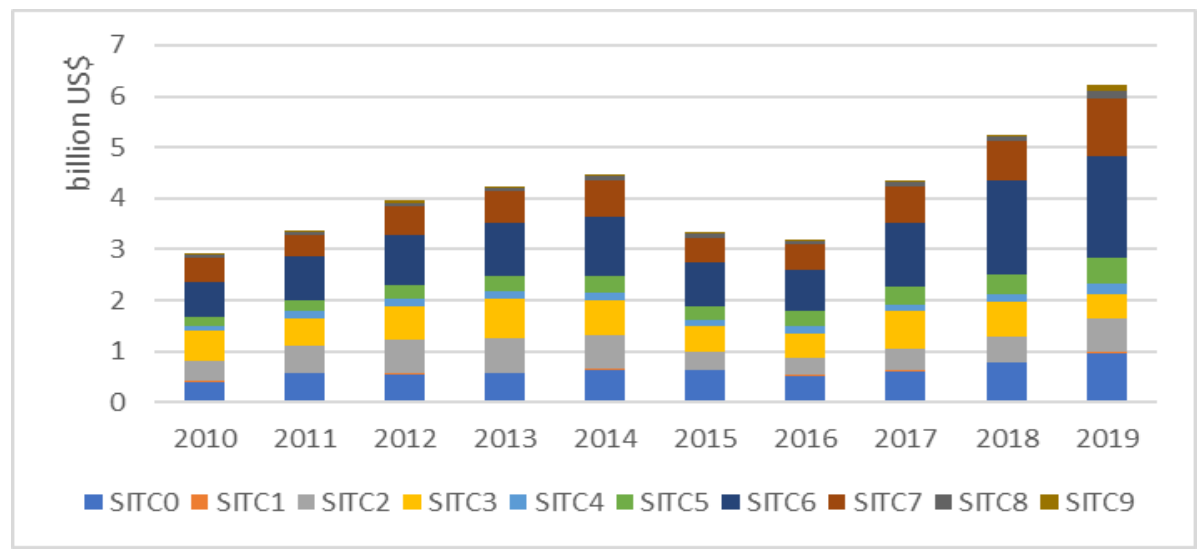




\author{
Zhang Lingzhi \\ Analysis on Trade Competitiveness and Trade Complementarity between Uzbekistan and the Member \\ States of Eurasian Economic Union
}

Figure 3: 2010-2019 Uzbekistan's import trade volume to the Eurasian Economic Union

Source: UN Comtrade Database

\title{
1.1 Problem Statement
}

As the trade exchanges between Uzbekistan and the member states of the Eurasian Economic Union continue to increase, it has not only expanded the trade space between Uzbekistan and the member states of the Eurasian Economic Union but also created opportunities for Uzbekistan to strengthen cooperation with the Eurasian Economic Union. In today's world, COVID-19 has not yet ended, anti-globalization has begun to appear, and the need to strengthen regional economic cooperation has become increasingly prominent. On the premise of giving full play to the resource endowments of various countries, how to use trade complementarity to promote economic and trade cooperation between Uzbekistan and the Eurasian Economic Union is an important issue worthy of study.

\subsection{Aim of the Study}

Based on the 2010-2019 UN Comtrade Database SITC (Rev.4) commodity trade data, the paper shows the trade relations and development trends between Uzbekistan and the member states of the Eurasian Economic Union. first, through Export similarity index (ESI) and Regional Revealed Comparative Advantage Index (RRCA) analysis, the comparative advantages of Uzbekistan's commodities traded in the member states of the Eurasian Economic Union was found, as well as the competitive commodity categories. Secondly, the complementary commodity categories were found by Trade Complementarity Index (TCI) and Grubel-Lloyd Intra-Industry Trade Index (GL) analysis. These analyses demonstrate the trade structure between Uzbekistan and the Eurasian Economic Union and draws a conclusion of trade complementarity, which provide a reference for the necessity of Uzbekistan to strengthen regional economic cooperation with the Eurasian Economic Union under the new situation.

\section{Literature Review}

There are a few studies on bilateral trade issues, and they mainly focus on the analysis of the status quo of bilateral trade, trade system and transportation conditions (Gael Raballand, 2007; Clemens Grafe, 2008; Madan B. Regmi, 2012; Farrukh Suvankulov, 2012). There is a lack of empirical analysis on bilateral trade in specific categories of commodities. Abra (2008), Ting Li (2011) and Xiaohui Qi (2016) mainly analysed the complementarity of agricultural trade between China and the five Central Asian countries based on the status and structure of bilateral trade. Huang Tao (2015) used variables such as GDP, GDP per capita, population, distance and added value of agricultural output to calculate the trade potential of major agricultural products between China (Xinjiang) and five Central Asian countries. Gao Zhigang (2015) used the variable tariff rate to estimate the trade potential between China and Central Asian countries. Yuan Zhou (2016) used the trade gravity model and introduced the degree of financial participation and partner country's export product structure as variables to analyze the influencing factors and trade potential of China's trade, and found that they play an important role in the potential of bilateral trade. According to the 2003-2013 China-Korea bilateral trade data, Jin Zhuqiao (2015) used trade integration, trade complementarity index and gravity model to conduct an empirical analysis of the trade status and trade potential between China and South Korea. The results show that the potential of bilateral trade between China and South Korea is gradually showing an increasing trend. Ma Jing (2009) calculated the trade integration index and trade complementarity index of relevant years and concluded that there is huge potential for trade development between China and developing countries. Based on the time series data from 1998 to 2007, Yang Guochuan (2010) used trade integration, trade competitive advantage index, trade complementarity index and current market share model to analyze the trade complementarity and trade potential between China and Canada. 


\section{Zhang Lingzhi \\ Analysis on Trade Competitiveness and Trade Complementarity between Uzbekistan and the Member \\ States of Eurasian Economic Union}

The above scholars have used different methods to study trade competitiveness and trade complementarity, which provides the necessary reference for the study of this paper. However, there is currently a lack of analysis of all commodities (SITC0-SITC9) from the perspective of trade competitiveness and trade complementarity by the trade index between Uzbekistan and the member states of the Eurasian Economic Union. Based on the UN Comtrade database commodity trade data (SITC0-SITC9, Rev.4), this paper analyses the trade competitiveness and trade complementarity between Uzbekistan and the member states of the Eurasian Economic Union. It provides references for Uzbekistan and the member states of Eurasian Economic Union to better carry out economic and trade cooperation.

\section{Research Methodology}

This paper focuses on the methodology of the research, and the method used is the index analysis method, such as the regional revealed comparative advantage index (RRCA), the export similarity index (ESI), the trade complementarity index (TCI) and the Grubel-Lloyd intraindustry trade index (GL). The index compares the trade competitiveness and trade complementarity between Uzbekistan and the member states of the Eurasian Economic Union. And look forward to the conclusion that Uzbekistan and the member states of the Eurasian Economic Union should strengthen economic and trade cooperation with the application of such methods.

\subsection{Export Similarity Index (ESI)}

$$
E S I_{i j k}=100 \times \sum_{l} \min \left(\frac{\exp _{i k}^{l}}{\exp _{i k}}, \frac{\exp _{j k}^{l}}{\exp _{j k}}\right)
$$

$E I_{i j k}$ is the export similarity index of country $i$ and country $j$ in the $k$ market, $\exp ^{l_{i k}}$ and $\exp _{j k}$ are the amount of country $i$ and country $j$ exported to the $k$ market. $\exp _{i k}$ and $\exp _{j k}$ are the total amount of goods exported to market $k$ from country $i$ and country $j$. The value of ESI varies between 0-100. The larger the value, the higher the similarity of the export structure of the two countries' products.

\subsection{Regional Revealed Comparative Advantage Index (RRCA)}

$$
\operatorname{RRCA}_{i c}=\left(X_{i c} / X_{t c}\right) /\left(X_{i R} / X_{t R}\right)
$$

$X_{i c}$ represents the value of export commodity i of country $c, X_{t c}$ represents the total export value of country $c, X_{i R}$ represents the value of export commodity $i$ of region $R$, and $X_{t R}$ represents the total export value of region R. If RRCA $>1$, it means that product $i$ of country $c$ has a comparative advantage in region $R$; if $R R C A<1$, it means that product $i$ of country $c$ does not have a comparative advantage in region $R$.

\subsection{Trade Complementarity Index (TCI)}

$$
\mathrm{TCI}_{\mathrm{ij}} \mathrm{RCA}_{\mathrm{yi}} \mathrm{RCA}^{\mathrm{a}}{ }_{\mathrm{lj}}
$$

$R_{C A}{ }_{y i}$ is the comparative advantage of country $i$ in exporting commodity $a$, and $R A^{a}{ }_{l j}$ is the comparative disadvantage of country $\mathrm{j}$ on imported products $\mathrm{a}$. It is generally believed that $\mathrm{TCI}>1$ means that both sides of the trade have high complementarity, while $\mathrm{TCI}<1$ is the opposite.

\subsection{Grubel-Lloyd Intra-Industry Trade Index (GL)}




\section{Zhang Lingzhi}

Analysis on Trade Competitiveness and Trade Complementarity between Uzbekistan and the Member

States of Eurasian Economic Union

$$
G L_{a}=\frac{\left(X_{a}+Y_{a}\right)-\left|X_{a}-Y_{a}\right|}{X_{a}+Y_{a}}
$$

$\mathrm{X}_{\mathrm{a}}, \mathrm{Y}_{\mathrm{a}}$ are the export and import trade volume of a specific industry or a specific commodity a, $\mathrm{GL}_{\mathrm{a}}>0.5$ means intra-industry trade is dominant, and $\mathrm{GL}_{\mathrm{a}}<0.5$ means industry Inter-trade is dominant.

\section{Data Analysis and Interpretation}

\subsection{Analysis of Trade Competitiveness}

In view of the similarities between Uzbekistan and the member states of the Eurasian Economic Union in terms of economic development levels and resource endowments, each country has its own comparative advantages in different types of commodities. Therefore, in order to more accurately measure the trade competitiveness between Uzbekistan and the member states of the Eurasian Economic Union, this paper uses the Export Similarity Index (ESI) and the Regional Display Comparative Advantage Index (RRCA) to describe the trade competitiveness of each country.

\subsubsection{Analysis of Trade and Export Similarity Index}

The analysis of the trade export similarity index (ESI), proposed by Michael and Kreinin (1979), is used to measure the competitive relationship between the two countries' exports of similar products in the same market. Through the analysis of the similarity of the export product structure, the Competitive relationship of the two countries is judged on the same market. The calculation formula is:

$$
E S I_{i j k}=100 \times \sum_{l} \min \left(\frac{\exp _{i k}^{l}}{\exp _{i k}}, \frac{\exp _{j k}^{l}}{\exp _{j k}}\right)
$$

$E S I_{i j k}$ is the export similarity index of country $i$ and country $j$ in the $k$ market, $\exp ^{l_{i k}}$ and $\exp ^{{ }_{j k}}$ are the amount of country $i$ and country $j$ exported to the $k$ market. $\exp _{i k}$ and $\exp _{j k}$ are the total amount of goods exported to market k from country $i$ and country $j$. It needs to be emphasized that the export similarity in this paper refers to the export similarity between countries in the world market. The value of ESI varies between 0-100. The larger the value, the higher the similarity of the export structure of the two countries' products. The lower the value, the stronger the complementarity between the two countries' exports to the same market.

Table 1: ESI of Uzbekistan and the member states of the Eurasian Economic Union

\begin{tabular}{|c|c|c|c|c|c|c|}
\hline YEAR & UZE-EAEU & UZB-ARM & UZB-BLR & UZB-KAZ & UZB-KGZ & UZB-RUS \\
\hline 2010 & 38.36 & 64.86 & 70.06 & 36.60 & 39.33 & 35.46 \\
\hline 2011 & 43.67 & 63.34 & 70.07 & 43.88 & 42.31 & 40.43 \\
\hline 2012 & 38.20 & 74.21 & 61.28 & 36.15 & 60.49 & 35.40 \\
\hline 2013 & 46.85 & 58.66 & 66.04 & 39.65 & 67.70 & 45.06 \\
\hline 2014 & 48.27 & 56.91 & 65.28 & 40.15 & 62.91 & 46.66 \\
\hline 2015 & 45.60 & 61.27 & 53.31 & 42.76 & 59.56 & 43.61 \\
\hline 2016 & 58.02 & 49.51 & 58.77 & 49.23 & 68.25 & 57.36 \\
\hline 2017 & 55.50 & 45.54 & 54.57 & 42.10 & 70.79 & 55.65 \\
\hline 2018 & 64.13 & 47.61 & 70.05 & 48.59 & 63.30 & 64.60 \\
\hline 2019 & 53.95 & 40.22 & 52.22 & 39.39 & 72.45 & 54.20 \\
\hline
\end{tabular}

Source: UN Comtrade Database, calculated by the author 


\section{Zhang Lingzhi}

Analysis on Trade Competitiveness and Trade Complementarity between Uzbekistan and the Member

States of Eurasian Economic Union

From Table 1, the ESI between Uzbekistan and the member states of the Eurasian Economic Union is greater than 30, and there are differences among countries. It shows that Uzbekistan and the Eurasian Economic Union member countries have a certain similarity in the export structure of commodities, and the export commodities are competitive in the same market. Judging from the perspective of development trends from 2010 to 2019, the ESI of UZB-ARM and UZB-BLR showed a fluctuating downward trend. The ESI of UZB-RUS, UZB-KAZ and UZBKGZ showed a fluctuating upward trend.

\subsubsection{Regional Revealed Comparative Advantage Index (RRCA)}

Revealed comparative advantage reflects the status of a country in international trade by comparing the proportion of a country's exports of a certain commodity with the proportion of the world's exports of that type of commodity. That is to place a country's export of a certain product under the framework of the global market and the overall commodity trade to compare its competitive advantage. Since the element structures of various countries and regions in the world are very different, it is better to divide the world into different regions and specifically study the comparative advantages of a country in different regions. This paper uses the Regional Revealed Comparative Advantage Index (RRCA) to study the comparative advantages of Uzbekistan and the member states of the Eurasian Economic Union. The revealed comparative advantage index of product $i$ of country $c$ in region $R$ is:

$$
\operatorname{RRCA}_{i c}=\left(X_{i c} / X_{t c}\right) /\left(X_{i R} / X_{t R}\right)
$$

$\mathrm{Xi}_{\mathrm{c}}$ represents the value of export commodity $\mathrm{i}$ of country $\mathrm{C}, \mathrm{X}_{\mathrm{tc}}$ represents the total export value of country $c, X_{i R}$ represents the value of export commodity $i$ of region $R$, and $X_{t R}$ represents the total export value of region $\mathrm{R}$. If $\mathrm{RRCA}>1$, it means that product $\mathrm{i}$ of country $\mathrm{c}$ has a comparative advantage in region $R$; if $R R C A<1$, it means that product $i$ of country $c$ does not have a comparative advantage in region $R$.

Table 2: RRCA index of Uzbekistan and the member states of the Eurasian Economic Union

\begin{tabular}{|c|c|c|c|c|c|c|c|c|c|c|c|}
\hline \multirow[t]{2}{*}{ country } & \multirow[t]{2}{*}{ year } & \multicolumn{5}{|c|}{ primary product } & \multicolumn{2}{|c|}{$\begin{array}{c}\text { Labor- } \\
\text { intensive } \\
\text { products }\end{array}$} & \multicolumn{3}{|c|}{$\begin{array}{l}\text { Capital (technology) } \\
\text { intensive products }\end{array}$} \\
\hline & & SITCO & SITC1 & SITC2 & SITC3 & SITC4 & SITC6 & SITC8 & SITC5 & SITC7 & SITC9 \\
\hline \multirow[t]{10}{*}{ UZB } & 2010 & 4.33 & 2.47 & 6.17 & 0.13 & 0.20 & 1.93 & 3.81 & 3.52 & 3.49 & 0.39 \\
\hline & 2011 & 5.29 & 2.71 & 4.41 & 0.25 & 0.01 & 2.12 & 4.28 & 2.46 & 4.49 & 0.28 \\
\hline & 2012 & 2.82 & 2.31 & 5.56 & 0.09 & 0.01 & 1.97 & 3.47 & 1.94 & 3.53 & 3.67 \\
\hline & 2013 & 2.46 & 1.36 & 4.03 & 0.23 & 0.00 & 1.68 & 2.46 & 1.86 & 2.24 & 6.25 \\
\hline & 2014 & 2.41 & 1.37 & 2.51 & 0.25 & 0.00 & 2.09 & 2.28 & 1.73 & 1.99 & 7.41 \\
\hline & 2015 & 1.65 & 0.86 & 3.06 & 0.18 & 0.00 & 1.78 & 1.64 & 1.64 & 0.33 & 8.08 \\
\hline & 2016 & 1.52 & 0.63 & 1.29 & 0.24 & 0.01 & 1.26 & 1.38 & 1.78 & 0.21 & 3.17 \\
\hline & 2017 & 1.57 & 0.73 & 0.83 & 0.19 & 0.00 & 1.39 & 2.05 & 1.62 & 0.44 & 3.27 \\
\hline & 2018 & 2.23 & 0.69 & 0.95 & 0.40 & 0.01 & 1.53 & 3.37 & 1.64 & 0.31 & 2.20 \\
\hline & 2019 & 1.30 & 0.64 & 0.60 & 0.23 & 0.01 & 1.65 & 1.90 & 1.07 & 0.33 & 3.55 \\
\hline \multirow[t]{7}{*}{ ARM } & 2010 & 1.59 & 63.35 & 7.21 & 0.06 & 0.02 & 3.55 & 3.65 & 0.26 & 0.96 & 0.51 \\
\hline & 2011 & 1.90 & 73.79 & 6.17 & 0.12 & 0.01 & 3.47 & 4.32 & 0.23 & 1.44 & 0.67 \\
\hline & 2012 & 1.97 & 64.55 & 5.93 & 0.11 & 0.01 & 2.62 & 3.61 & 0.24 & 1.57 & 1.94 \\
\hline & 2013 & 2.44 & 65.50 & 6.42 & 0.09 & 0.00 & 2.80 & 4.64 & 0.36 & 0.69 & 1.42 \\
\hline & 2014 & 1.90 & 61.35 & 5.91 & 0.09 & 0.00 & 2.80 & 4.92 & 0.26 & 0.39 & 1.96 \\
\hline & 2015 & 1.52 & 44.46 & 6.80 & 0.10 & 0.01 & 1.71 & 4.80 & 0.23 & 0.33 & 1.98 \\
\hline & 2016 & 1.28 & 43.82 & 5.40 & 0.07 & 0.07 & 1.32 & 5.28 & 0.22 & 0.36 & 0.70 \\
\hline
\end{tabular}


Zhang Lingzhi

Analysis on Trade Competitiveness and Trade Complementarity between Uzbekistan and the Member

States of Eurasian Economic Union

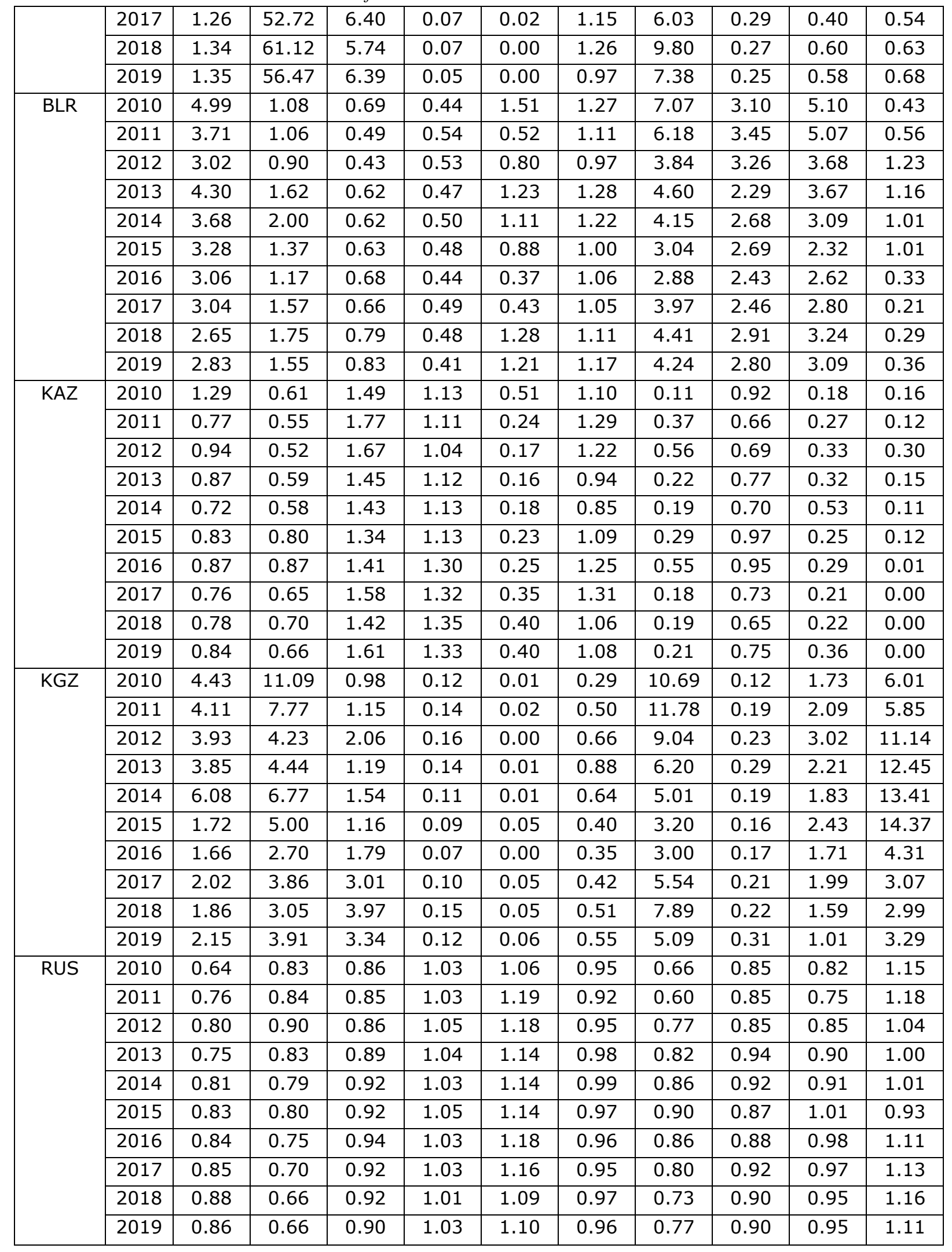

Source: UN Comtrade Database, calculated by the author

Table 2 lists the comparative advantages of Uzbekistan and the countries of the Eurasian Economic Union in various commodities trade from 2010 to 2019. From the perspective of 


\section{Zhang Lingzhi}

Analysis on Trade Competitiveness and Trade Complementarity between Uzbekistan and the Member

States of Eurasian Economic Union

commodity trade classification: Uzbekistan's commodity trade advantages are mainly laborintensive products SITC6 and SITC8, and the advantages of primary products SITCO and capital (technology)-intensive products SITC5 and SITC9 are also more obvious. From the perspective of the ten-year RRCA index trend, the advantages of primary products SITC0, SITC1, SITC2 and capital (technology)-intensive products SITC5 and SITC7 are on a downward trend, while the advantages on SITC9 are on the rise.

Among the member states of the Eurasian Economic Union, Russia's commodity trade advantages are concentrated in energy-related primary products SITC3 and SITC4. Kazakhstan's commodity trade advantages are concentrated in SITC2, SITC3 and SITC6, mainly mineral energy and light industrial products. In addition to SITC2, SITC3 in the mineral energy category and SITC9 in other categories, Belarus has comparative trade advantages in the remaining seven categories of commodities, especially in capital (technology)-intensive commodity trade. The advantages of Kyrgyzstan and Armenia in commodity trade are mainly concentrated in primary products, especial agricultural primary products SITC0, SITC1, SITC2 and miscellaneous manufactured articles SITC8. In addition, Kyrgyzstan has an advantage in SITC7 and a clear advantage in SITC9.

From the perspective of commodity trade competitiveness: Uzbekistan is highly competitive on SITC9 in the region composed of Uzbekistan and the member states of the Eurasian Economic Union. Belarus is highly competitive in SITC0, SITC5, SITC7 and SITC8. Kyrgyzstan has strong competitiveness in SITC0, SITC1, SITC2, SITC8 and SITC9. Armenia has strong competitiveness in SITC1, SITC2 and SITC8. In terms of product classification that is highly competitive between Uzbekistan and the member states of the Eurasian Economic Union, Uzbekistan and Kyrgyzstan are highly competitive on SITC9, while other categories of commodities are not very competitive.

Table 3: Classification of RRCA between Uzbekistan and the member states of the Eurasian Economic Union

\begin{tabular}{|c|c|c|c|c|}
\hline COUNTRY & $0 \leq R R C A<0.5$ & $0.5 \leq R R C A<1$ & $1 \leq \mathrm{RRCA}<2$ & $2 \leq \mathrm{RRCA}$ \\
\hline UZB & SITC3 SITC4 SITC7 & SITC1 SITC2 & $\begin{array}{l}\text { SITC0 SITC6 } \\
\text { SITC8 SITC5 }\end{array}$ & SITC9 \\
\hline ARM & SITC3 SITC4 SITC5 & $\begin{array}{l}\text { SITC6 SITC7 } \\
\text { SITC9 }\end{array}$ & SITCO & $\begin{array}{l}\text { SITC1 SITC2 } \\
\text { SITC8 }\end{array}$ \\
\hline BLR & SITC3 SITC9 & SITC2 & $\begin{array}{l}\text { SITC1 SITC4 } \\
\text { SITC6 }\end{array}$ & $\begin{array}{l}\text { SITC0 SITC8 } \\
\text { SITC5 SITC7 }\end{array}$ \\
\hline KAZ & $\begin{array}{c}\text { SITC4 SITC8 SITC7 } \\
\text { SITC9 }\end{array}$ & $\begin{array}{l}\text { SITCO SITC1 } \\
\text { SITC5 }\end{array}$ & $\begin{array}{l}\text { SITC2 SITC3 } \\
\text { SITC6 }\end{array}$ & - \\
\hline KGZ & SITC3 SITC4 SITC5 & SITC6 & SITC7 & $\begin{array}{l}\text { SITC0 SITC1 } \\
\text { SITC2 SITC8 } \\
\text { SITC9 }\end{array}$ \\
\hline RUS & - & $\begin{array}{l}\text { SITC0 SITC1 } \\
\text { SITC2 SITC6 }\end{array}$ & $\begin{array}{l}\text { SITC3 SITC4 } \\
\text { SITC9 }\end{array}$ & - \\
\hline
\end{tabular}




\section{Zhang Lingzhi}

Analysis on Trade Competitiveness and Trade Complementarity between Uzbekistan and the Member States of Eurasian Economic Union

\begin{tabular}{|l|l|c|l|l|}
\hline & $\begin{array}{c}\text { SITC8 SITC5 } \\
\text { SITC7 }\end{array}$ & & \\
\hline
\end{tabular}

Source: UN Comtrade Database, calculated by the author

\subsection{Analysis of Trade Complementarity}

\subsubsection{Trade Complementarity Index (TCI)}

The TCI measures the complementarity of trade on the basis of comparing the comparative advantages of the import and export of bilateral countries. It is used to measure the complementarity of commodity trade. The formula is as follows:

$$
\operatorname{TCI}^{a_{i j}}=\operatorname{RCA}^{a_{y i}} * R C^{a_{1 j}}
$$

$\mathrm{RCA}^{\mathrm{a}} \mathrm{yi}$ is the comparative advantage of country $\mathrm{i}$ in exporting commodity a, and the formula is: $R C A_{y i}^{a}=\frac{S_{i a}}{S_{i t}} . \mathrm{S}_{\mathrm{ia}}$ is the ratio of the export value of country i's a product to the world export value of a product, $S_{i t}$ is the ratio of the total export commodities of country $i$ to the total export commodities of the world. RCA ${ }^{a}$ ij is the comparative disadvantage of country $j$ on imported products a, and the formula is: $R C A_{l j}^{a}=\frac{W_{j a}}{W_{j t}} . \mathrm{W}_{\mathrm{ja}}$ is the ratio of the import value of a product in country $j$ to the import value of a product in the world, and $W_{j t}$ is the ratio of the total value of imports from country $j$ to the total value of world imports. It is generally believed that TCI $>1$ means that both sides of the trade have high complementarity, while $\mathrm{TCI}<1$ is the opposite.

Table 4: TCI between Uzbekistan and the member states of the Eurasian Economic Union

\begin{tabular}{|l|l|l|l|l|l|l|l|l|l|l|l|l|}
\hline \multirow{2}{*}{ YEAR } & \multicolumn{2}{l|}{ ARM } & \multicolumn{2}{l|}{ BLR } & \multicolumn{2}{l|}{ KAZ } & \multicolumn{2}{l|}{ KGZ } & \multicolumn{2}{l|}{ RUS } & \multicolumn{2}{l|}{ EAEU } \\
\cline { 2 - 16 } & $\begin{array}{l}\text { UZB- } \\
\text { ARM }\end{array}$ & $\begin{array}{l}\text { ARM- } \\
\text { UZB }\end{array}$ & $\begin{array}{l}\text { UZB- } \\
\text { BLR }\end{array}$ & $\begin{array}{l}\text { BLR- } \\
\text { UZB }\end{array}$ & $\begin{array}{l}\text { UZB- } \\
\text { KAZ }\end{array}$ & $\begin{array}{l}\text { KAZ- } \\
\text { UZB }\end{array}$ & $\begin{array}{l}\text { UZB- } \\
\text { KGZ }\end{array}$ & $\begin{array}{l}\text { KGZ- } \\
\text { UZB }\end{array}$ & $\begin{array}{l}\text { UZB- } \\
\text { RUS }\end{array}$ & $\begin{array}{l}\text { RUS- } \\
\text { UZB }\end{array}$ & $\begin{array}{l}\text { UZB- } \\
\text { EAEU }\end{array}$ & $\begin{array}{l}\text { EAEU- } \\
\text { UZB }\end{array}$ \\
\hline 2010 & 1.50 & 2.06 & 1.35 & 0.98 & 1.01 & 0.74 & 1.50 & 1.01 & 1.35 & 0.72 & 1.33 & 0.74 \\
\hline 2011 & 1.52 & 1.99 & 1.18 & 0.84 & 1.03 & 0.63 & 1.52 & 1.04 & 1.17 & 0.67 & 1.16 & 0.68 \\
\hline 2012 & 1.61 & 2.81 & 1.19 & 0.99 & 1.10 & 0.72 & 1.61 & 1.31 & 1.16 & 0.83 & 1.16 & 0.83 \\
\hline 2013 & 1.43 & 2.62 & 1.18 & 1.18 & 0.84 & 0.65 & 1.43 & 1.13 & 0.94 & 0.84 & 0.96 & 0.84 \\
\hline 2014 & 1.63 & 2.30 & 1.43 & 1.19 & 0.88 & 0.64 & 1.63 & 1.19 & 0.94 & 0.89 & 0.99 & 0.88 \\
\hline 2015 & 1.37 & 2.24 & 1.58 & 1.27 & 0.95 & 0.89 & 1.37 & 0.87 & 1.03 & 1.08 & 1.10 & 1.07 \\
\hline 2016 & 1.28 & 2.23 & 1.55 & 1.20 & 0.89 & 1.10 & 1.28 & 1.24 & 0.70 & 1.49 & 0.82 & 1.44 \\
\hline 2017 & 1.24 & 1.99 & 1.12 & 1.13 & 0.83 & 1.11 & 1.24 & 1.05 & 0.69 & 1.23 & 0.76 & 1.22 \\
\hline 2018 & 1.34 & 1.89 & 1.36 & 1.28 & 0.94 & 0.82 & 1.34 & 1.19 & 0.90 & 1.06 & 0.97 & 1.05 \\
\hline 2019 & 1.38 & 1.97 & 1.46 & 1.49 & 1.00 & 0.88 & 1.38 & 1.43 & 0.88 & 1.27 & 0.97 & 1.25 \\
\hline
\end{tabular}

Source: UN Comtrade Database, calculated by the author

From the perspective of trade complementarity, Uzbekistan's trade complementarity with the member states of the Eurasian Economic Union is mainly concentrated in SITC0, SITC3, SITC6 and SITC9. The advantage of SITC6 is the most obvious for Kyrgyzstan, with a TCI value of 3.7, and the advantage of SITC9 is the most obvious for Belarus, with a TCI value of 6.6. Uzbekistan has strong trade complementarity with Armenia, Belarus and Kyrgyzstan, with TCI values above 1. Uzbekistan's trade complementarity with Russia and Kazakhstan is weak. The trade complementary advantages of the member states of the Eurasian Economic Union with Uzbekistan are concentrated in SITC0, SITC2 and SITC6. Russia and Belarus have extremely 


\section{Zhang Lingzhi}

Analysis on Trade Competitiveness and Trade Complementarity between Uzbekistan and the Member

States of Eurasian Economic Union

strong trade complementarity with Uzbekistan on SITC4, and their TCI values are both above 4. Kyrgyzstan has shown strong trade complementarity with Uzbekistan on SITC2 and SITC9, and Armenia has shown strong trade complementarity with Uzbekistan on SITC1 and SITC2. Among the member states of the Eurasian Economic Union, with the exception of Kazakhstan, the other member states have strong trade complementarity with Uzbekistan.

From the perspective of trade trends, from 2010 to 2019, Uzbekistan's trade complementarity with Russia, a member of the Eurasian Economic Union, showed a weakening trend. However, the trade complementarity of the member states with Uzbekistan has shown a clear upward trend.

Table 5: Classification of TCI between Uzbekistan and the member states of the EAEU

\begin{tabular}{|c|c|c|c|c|c|c|c|c|c|}
\hline COUNTRY & $\begin{array}{l}1 \leq \mathrm{TCI} \\
=2\end{array}$ & $\begin{array}{l}2 \leq \mathrm{TCI} \\
<3\end{array}$ & $\begin{array}{l}3 \leq \mathrm{TCI} \\
<4\end{array}$ & $4 \leq \mathrm{TCI}$ & COUNTRY & $\begin{array}{l}1 \leq \mathrm{TCI} \\
<2\end{array}$ & $\begin{array}{l}2 \leq \mathrm{TCI} \\
<3\end{array}$ & $\begin{array}{l}3 \leq \mathrm{TCI} \\
<4\end{array}$ & $4 \leq \mathrm{TCI}$ \\
\hline UZB-EEU & SITCO & SITC6 & SITC9 & - & EEU-UZB & $\begin{array}{l}\text { SITC2 } \\
\text { SITC3 } \\
\text { SITC6 } \\
\text { SITC9 }\end{array}$ & - & - & SITC4 \\
\hline UZB-ARM & $\begin{array}{l}\text { SITC1 } \\
\text { SITC3 }\end{array}$ & SITCO & SITC6 & SITC9 & ARM-UZB & $\begin{array}{l}\text { SITC0 } \\
\text { SITC6 } \\
\text { SITC9 }\end{array}$ & - & - & $\begin{array}{l}\text { SITC1 } \\
\text { SITC2 }\end{array}$ \\
\hline UZB-BLR & SITCO & $\begin{array}{l}\text { SITC3 } \\
\text { SITC6 }\end{array}$ & - & SITC9 & BLR-UZB & $\begin{array}{l}\text { SITC2 } \\
\text { SITC5 }\end{array}$ & $\begin{array}{l}\text { SITC0 } \\
\text { SITC6 }\end{array}$ & - & SITC4 \\
\hline UZB-KAZ & SITCO & - & $\begin{array}{l}\text { SITC6 } \\
\text { SITC9 }\end{array}$ & - & KAZ-UZB & $\begin{array}{l}\text { SITC2 } \\
\text { SITC3 } \\
\text { SITC4 }\end{array}$ & SITC6 & - & - \\
\hline UZB-KGZ & $\begin{array}{l}\text { SITC0 } \\
\text { SITC3 }\end{array}$ & - & SITC6 & - & KGZ-UZB & $\begin{array}{l}\text { SITC0 } \\
\text { SITC6 }\end{array}$ & - & - & $\begin{array}{l}\text { SITC2 } \\
\text { SITC9 }\end{array}$ \\
\hline BZB-RUS & $\begin{array}{l}\text { SITC0 } \\
\text { SITC6 }\end{array}$ & SITC9 & - & - & RUS-UZB & $\begin{array}{l}\text { SITC2 } \\
\text { SITC3 } \\
\text { SITC6 } \\
\text { SITC9 }\end{array}$ & - & - & SITC4 \\
\hline
\end{tabular}

Source: UN Comtrade Database, calculated by the author

\subsubsection{Gruber-Lloyd Intra-Industry Trade Index (GL)}

The GL index was proposed by Grubel H.G. and Lloyd P.J. (1975). They believe that trade can be divided into intra-industry trade and inter-industry trade. The formula is as follows:

$$
G L_{a}=\frac{\left(X_{a}+Y_{a}\right)-\left|X_{a}-Y_{a}\right|}{X_{a}+Y_{a}}
$$

$X_{a}, Y_{a}$ are the export and import trade volume of a specific industry or a specific commodity $a$, and the value of $G L_{a}$ is between $0-1$. When $X_{a}=Y_{a}, G L_{a}=1$, which means all trade is an industry Intra-industry trade. When $X_{a}=0$ or $Y_{a}=0, G_{a}=0$, it means all trade is inter-industry trade. 


\section{Zhang Lingzhi}

Analysis on Trade Competitiveness and Trade Complementarity between Uzbekistan and the Member

States of Eurasian Economic Union

$\mathrm{GL}_{\mathrm{a}}>0.5$ means intra-industry trade is dominant, and $\mathrm{GL}_{\mathrm{a}}<0.5$ means industry Inter-trade is dominant.

Table 6: Intra/inter-industry trade between Uzbekistan and Eurasian Economic Union member states

\begin{tabular}{|c|c|c|c|c|}
\hline COUNTRY & Inter-industry trade & Intra-industry trade & $\begin{array}{c}\text { Type of } \\
\text { trade }\end{array}$ & $\begin{array}{c}\text { GL index } \\
\text { trend }\end{array}$ \\
\hline UZB-EEU & $\begin{array}{l}\text { SITC2 SITC3 SITC4 } \\
\text { SITC6 SITC7 SITC9 }\end{array}$ & $\begin{array}{l}\text { SITC0 SITC1 SITC5 } \\
\text { SITC8 }\end{array}$ & $\begin{array}{c}\text { Inter- } \\
\text { industry }\end{array}$ & decline \\
\hline UZB-ARM & $\begin{array}{c}\text { SITC0 SITC1 SITC2 } \\
\text { SITC5 SITC6 SITC7 } \\
\text { SITC8 }\end{array}$ & - & $\begin{array}{l}\text { Inter- } \\
\text { industry }\end{array}$ & decline \\
\hline UZB-BLR & $\begin{array}{l}\text { SITC2 SITC3 SITC4 } \\
\text { SITC5 SITC7 }\end{array}$ & $\begin{array}{c}\text { SITC0 SITC1 SITC6 } \\
\text { SITC8 }\end{array}$ & $\begin{array}{c}\text { Inter- } \\
\text { industry }\end{array}$ & rise \\
\hline UZB-KAZ & $\begin{array}{l}\text { SITC2 SITC4 SITC6 } \\
\text { SITC9 }\end{array}$ & $\begin{array}{l}\text { SITC0 SITC1 SITC3 } \\
\text { SITC5 SITC7 SITC8 }\end{array}$ & $\begin{array}{l}\text { Inter- } \\
\text { industry }\end{array}$ & constant \\
\hline UZB-KGZ & $\begin{array}{l}\text { SITC0 SITC1 SITC2 } \\
\text { SITC4 SITC5 SITC8 }\end{array}$ & SITC3 SITC6 SITC7 & $\begin{array}{c}\text { Inter- } \\
\text { industry }\end{array}$ & rise \\
\hline UZB-RUS & $\begin{array}{l}\text { SITC2 SITC3 SITC4 } \\
\text { SITC6 SITC7 SITC9 }\end{array}$ & $\begin{array}{c}\text { SITC0 SITC1 SITC5 } \\
\text { SITC8 }\end{array}$ & $\begin{array}{l}\text { Inter- } \\
\text { industry }\end{array}$ & constant \\
\hline
\end{tabular}

Source: UN Comtrade Database, calculated by the author

According to the analysis of the GL index: First, the commodity trade between Uzbekistan and the member states of the Eurasian Economic Union is mainly inter-industry trade. Second, in terms of commodity categories, the inter-industry trade between Uzbekistan and the member states of the Eurasian Economic Union is mainly concentrated on primary products SITC2, SITC3 and SITC4, capital (technology) intensive products SITC7 and SITC9, and labor-intensive products SITC6. Third, from the perspective of development trends, Uzbekistan and the member states of the Eurasian Economic Union are showing a trend of inter-industry trade. The trend of inter-industry trade between Uzbekistan and Armenia is obvious. There is a tendency to shift to intra-industry trade with Belarus and Kyrgyzstan. Uzbekistan maintains the trend of interindustry trade with Russia and Kazakhstan. It can be seen that Uzbekistan and the member states of the Eurasian Economic Union mainly focus on inter-industry trade, which fully reflects the trade complementarity between Uzbekistan and the member states of the Eurasian Economic Union. 


\section{Zhang Lingzhi}

Analysis on Trade Competitiveness and Trade Complementarity between Uzbekistan and the Member

States of Eurasian Economic Union

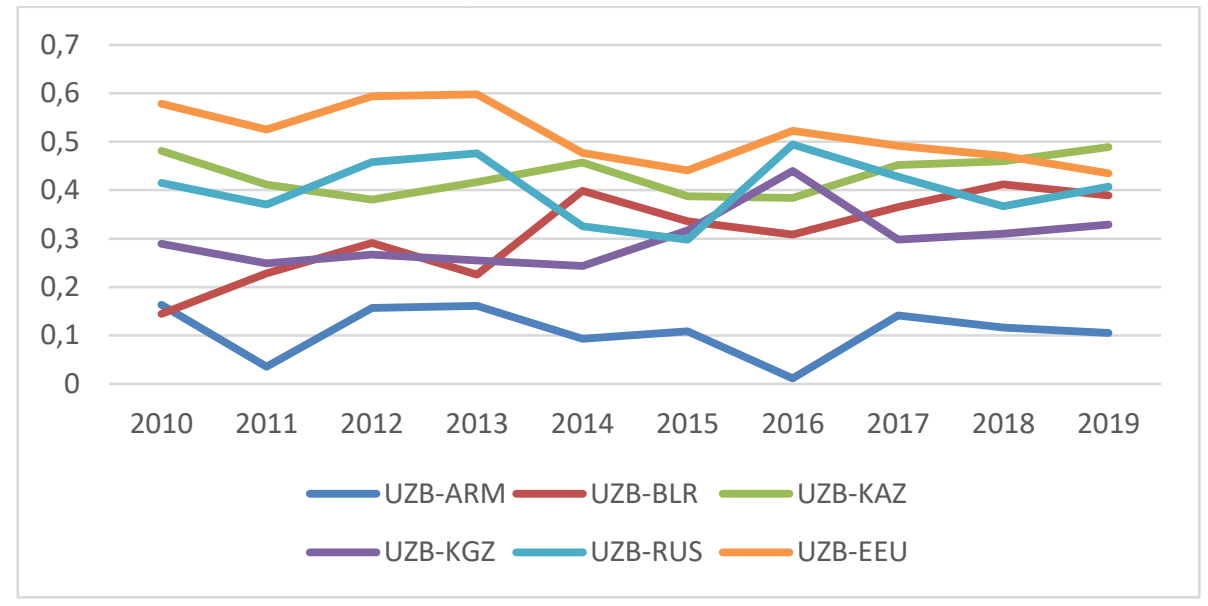

Figure 4: The trend of GL index between Uzbekistan and the member states of the Eurasian Economic Union

Source: UN Comtrade Database, calculated by the author

\section{Conclusion and Recommendations}

This paper is the first time that Uzbekistan and the member states of the Eurasian Economic Union are the research objects in the existing research to study their trade competitiveness and trade complementarity. In terms of research methods, this paper applies four trade indexes to study the trade competitiveness and trade complementarity between Uzbekistan and the member states of the Eurasian Economic Union for the first time in similar research. For example, by applying Trade Complementarity Index (ESI) and Regional Revealed Comparative Advantage Index (RRCA), Uzbekistan has a comparative advantage in commodity trade with the member states of the Eurasian Economic Union. By applying Trade Complementarity Index (TCI) and Grubel-Lloyd Intra-Industry Trade Index (GL), complementary product categories have been discovered. The data in this paper comes from the UN Comtrade Database, using the latest revised SITC (Rev.4) commodity trade data. This paper is the first to use SITC (Rev.4) data to study trade competitiveness and trade complementarity between Uzbekistan and the member states of the Eurasian Economic Union.

Through analysis, it is found that the trade competitiveness and trade complementarity between Uzbekistan and the member states of the Eurasian Economic Union present the following characteristics:

Uzbekistan and the member countries of the Eurasian Economic Union have a high degree of similarity in exports of goods, and there is a certain degree of competitiveness in goods exported to the same market. But at the same time, there are differences in the structure of commodity trade among member states. Uzbekistan's commodity trade advantages are mainly in laborintensive products SITC6 and SITC8, and its advantages in primary products SITCO and capital (technology)-intensive products SITC5 and SITC9 are also more obvious. Uzbekistan is highly competitive on SITC9. Belarus is highly competitive in SITC0, SITC5, SITC7 and SITC8. Kyrgyzstan is highly competitive in SITC0, SITC1, SITC2, SITC8 and SITC9. Armenia is highly competitive on SITC1, SITC2 and SITC8. In addition to Uzbekistan's strong competitiveness with Kyrgyzstan on SITC9, the trade of other categories of goods is not highly competitive with the member states.

Uzbekistan's trade complementarity with the member states of the Eurasian Economic Union is distributed in SITC0, SITC3, SITC6 and SITC9. Uzbekistan has strong trade complementarity with Armenia, Belarus, and Kyrgyzstan, and weak trade complementarity with Russia and 


\section{Zhang Lingzhi}

Analysis on Trade Competitiveness and Trade Complementarity between Uzbekistan and the Member

States of Eurasian Economic Union

Kazakhstan. Except for Kazakhstan, the other member states have strong trade complementarity with Uzbekistan. In addition, Uzbekistan and the member states of the Eurasian Economic Union mainly focus on inter-industry trade, which fully reflects Uzbekistan's trade complementarity.

In short, the trade characteristics of Uzbekistan and the Eurasian Economic Union are mainly complementary. The trade volume between Uzbekistan and the Eurasian Economic Union will continue to grow in the future. Regardless of geographical location or market size, the Eurasian Economic Union is an important economic and trade partner of Uzbekistan. In the future, Uzbekistan and the Eurasian Economic Union should strengthen trade cooperation in advantageous areas, promote trade integration, and reduce trade costs.

\section{Acknowledgements}

The author is very grateful to his doctoral supervisor, Professor M. Amonboev. Ph.D. You Lijie and Ms. Ma Cuiling provided a lot of help for this paper. Special thanks to the editors of this journal for their many valuable comments on the previous edition, which have improved its quality and content to its current state.

\section{References}

- Gael Raballand, Agnes, Andresy., (2007). Why should trade between Central Asia and China continue to expand. Springer. CrossRef

- Clemens Grafe, Martin Rasier. (2008). Toshiaki Sakatsume Beyondborders-Reconsidering regional trade in Central Asia. Joumal of Comparative Eeonomies. CrossRef

- Madan B, Regmi, Syinya Hanaoka. (2012). Assessment of inter- modal transport corridors: Cases from North- East and Central Asia. Research in Transportation Business \& management. CrossRef

- Farrukh Suvankulov, Yunnus Guc. (2012). Who is trading well in Central Asia? A Gravity analysis of Exports from the regional Powers to the Region. Eurasian Journal of Bussiness and Economics.

- Balassa B. (1965). Tradeliberalization among Industrial Countries: Objectives and Alternatives. New York: McGraw-Hill.

- Glick R, Rose A.M. (1999). Contagion and Trade: Why are Currency Crises Regional? Journal of International Money and Finance. CrossRef

- Selahattin. D. (2000). Aggregate Supply. Domestic Absorption, Term and Trade: A structural Decomposition of the US. Trade Balance. The internal Trade Journal. CrossRef

- Chou W. (2000) Exchange rate variability and China's exports. Journal of Comparative Economic. CrossRef

- Baharumsmhah. (2001). The effects of exchange rate on bilateral trade balance: new evidence from Malaysia and Thai-land. Asian Economic Journal. CrossRef

- Finger J M. Kreinin M E. (1979). A Measure of Export Similarity and its Possible Uses. Economic Journal. CrossRef

- Yu Jinping. (2003). Comparative advantages and trade complementarity between China and major East Asian countries and regions. World Economy.

- Han Yonghui. Research on the Competitiveness and Complementarity of Trade Cooperation between China and West Asia. World Economic Research.

- Jin Zhuiqiao, Yang Fengmin. (2015). An Empirical Study on the Status Quo and Potential of China-Korea Bilateral Trade. World Economy.

- Buwaa.Abra. (2008). Analysis of China's agriculture and its complementarity with China's agriculture. Issues of Agricultural Economy.

- Li Ting, Li Yuxin. (2011). Complementarity analysis of agricultural product trade between China and the five Central Asian countries. International Trade Issues. 


\section{Zhang Lingzhi}

Analysis on Trade Competitiveness and Trade Complementarity between Uzbekistan and the Member

States of Eurasian Economic Union

- Chen Jian, Buwaa.Abra. (2014). Research on Agricultural Products Trade Model between China and Five Central Asian Countries. International Trade Issues.

- Huang Tao, Sun Hui, Ma De. (2015). An Empirical Analysis of the Trade Potential between Xinjiang and Central Asia under the Background of the "Silk Road Economic Belt"--Gravity model based on panel data. Xinjiang Social Sciences.

- Gao Zhigang, Liu Wei. (2015). Calculation of the trade potential and prospects between China and the five Central Asian countries under the background of the "One Belt". Journal of Shandong University: Philosophy and Social Sciences Edition.

- Yuan Zhou, He Lunzhi. (2016). Analysis of the trade relationship in the core area of the Silk Road Economic Belt and China's response: A study based on the extended trade gravity model. Journal of Xinjiang Normal University: Philosophy and Social Sciences Edition.

- He Shufeng, Ping Ying, Zhang Weihua. (2013). The influence of the Arctic waterway on China's trade potential--An empirical study based on the stochastic frontier gravity model. International Trade Issues.

- On the state of mutual trade between the member states of the Eurasian Economic Union in 2016-2017.

- Committee of the Eurasian Economic Union. Eurasian Economic Union: Relations with the Outside World. 